\section{Partial Separation of Rat Liver Mitochondrial Amine Oxidases}

Axthovgr the mitochondrial monoamine oxidase (monoamine: $\mathrm{O}_{2}$-oxidoreductase (deaminating), $E C$ 1.4.3.4) is generally believed to possess broad substrate specificity ${ }^{1}$, numerous results may be considered as indirect evidence of 'multiplicity' of mitochondrial amino oxidases ${ }^{2-7}$. Novortheless, separation of mitochondrial amine oxidases has not so far beon reported to my knowledge.

This communication describes an example of partial separation of rat liver mitochondrial amine oxidases attacking two different amines suitable for spectrophotometric determination of the enzymatic activity, namoly, $m$-nitro-p-hydroxybenzylamine (PHB) (ref. 8) and $p$-nitrophenylethylamino (PN) (ref. 9).

Both substrates were synthesized by Dr. N. A. Kitrossky and G. A. Leontyova (Department of Organic Chemistry, Institute of Biological and Medical Chemistry). Mitochondria prepared from rat liver homogenates ${ }^{10}$ were treated by hypotonic phosphate ${ }^{11}$, solubilized in the presonce of a non-ionic detergent ' $O P$ '-10' (final concentra. tion $1 \cdot 25$ per cent) as described, earlier ${ }^{12}$ and adjusted to $p \mathrm{H} \mathrm{7.00.} \mathrm{All} \mathrm{the} \mathrm{subsequent} \mathrm{operations} \mathrm{were} \mathrm{performed,}$ at $3^{\circ}$. The solubilized material was applied to a $24 \mathrm{~mm} \times$ $95 \mathrm{~mm}$ 'Brushite' column ${ }^{13,14}$. Stepwise elution by $0 \cdot 1$, $0.4,0.5$ and $0.7 \mathrm{M}$ potassium-phosphate buffers, $p \mathrm{H} 7.00$, containing 1.25 per cent $(\mathrm{w} / \mathrm{v})$ of ' $O P-10$ ', was carried out. $15 \mathrm{-ml}$. fractions of effluent were collected at a flow rate of $4 \mathrm{ml} / \mathrm{min}$. Protein content was determined by the method of Lowry et al. ${ }^{15}$ with precautions necessary when working in presence of phosphates and dotergents ${ }^{16}$. PHB oxidation was followed by measuring optical density increase (due to formation of $m$-nitro- $p$-hydroxybenzaldehyde) at $315 \mathrm{~m} \mu$ in $10-\mathrm{mm}$ cuvettes put in a thermostat at $37^{\circ}$ (spectrophotometer $S F-4$ ) for 5 min. The samples containing $0.2 \mathrm{M}$ potassium-phosphate buffer $(0.5 \mathrm{ml}$. $)$, enzyme solutions $(0 \cdot 2-2.0 \mathrm{ml}$ ), PHB (final concentration $5 \cdot 3 \times 10^{-4} \mathrm{M}$ ) were brought up to $3.0 \mathrm{ml}$. with water. The spectrophotometric unit (SU) was defined as a quantity of enzyme necessary to cause an increase in optical density by 0.001 in 1 min. For PN oxidation assay PHB in samples described was substituted by $\mathrm{PN}$ (1 $\mathrm{mg}$ per sample) and after incubation at $37^{\circ}$ during $2 \mathrm{~h}$ optical density moasurements at $453 \mathrm{~m} \mu$ in $10-\mathrm{mm}$ cuvettes of 'FEKN-57' photoelectric colorimeter were taken. The assay yields fairly reproducible results and proved to be very sensitive. The quantity of the enzyme necessary to cause the optical density increase by 0.01 in the standard. conditions was defined as a unit (un.) of enzymatic activity. Table 1. Partial separation of Rat Liver Mrtochonnrial amine

\begin{tabular}{|c|c|c|c|c|c|c|}
\hline & & \\
\hline & \multirow{2}{*}{$\begin{array}{c}\text { Starting } \\
\text { mate- } \\
\text { rial }\end{array}$} & \multicolumn{4}{|c|}{ Combined effuent fractions } & \multirow{2}{*}{$\begin{array}{c}\text { Re- } \\
\text { covery } \\
(\%)\end{array}$} \\
\hline & & $1-8$ & $9-16$ & $17-25$ & $26-34$ & \\
\hline Volume (ml.) & $20 \cdot 0$ & $131 \cdot 2$ & $131 \cdot 0$ & $149 \cdot 5$ & $135 \cdot 5$ & \\
\hline $\begin{array}{l}\text { Phosphate concen- } \\
\text { tration }(\mathrm{M} / \mathrm{l})\end{array}$ & $0 \cdot 1$ & 0.1 & $0 \cdot 4$ & 0.5 & 0.7 & \\
\hline Protein content & 9,25 & 0.205 & & & & \\
\hline$\underset{\text { Total }}{\mathrm{mg} / \mathrm{ml}}$ & $\begin{array}{l}2 \cdot 25 \\
45 \cdot 0\end{array}$ & $\begin{array}{l}0 \cdot 225 \\
29 \cdot 32\end{array}$ & $\begin{array}{l}0.06 \\
7.86\end{array}$ & $\begin{array}{l}0 \cdot 02 \\
2 \cdot 99\end{array}$ & $\begin{array}{l}0 \cdot 02 \\
2 \cdot 71\end{array}$ & $95 \cdot 2$ \\
\hline PJYB-deamination & 700 & 0.0 & 0.0 & 200 & & \\
\hline Total & $800 \cdot 0$ & 0 & 0 & 37.5 & $12 \cdot 5$ & $6 \cdot 25$ \\
\hline $\begin{array}{l}\text { SU/mg of yrotein } \\
\text { (max.) } \\
\text { PN-deamination }\end{array}$ & $17 \cdot 8$ & $0 \cdot 0$ & $0 \cdot 0$ & $125 \cdot 0$ & $50 \cdot 0$ & \\
\hline $\begin{array}{l}\text { Tn./ml. (max.) } \\
\text { Total }\end{array}$ & $\begin{array}{r}67 \cdot 5 \\
1,350 \cdot 0\end{array}$ & $\begin{array}{r}1 \cdot 0 \\
13 \cdot 0\end{array}$ & $\begin{array}{r}19 \cdot 5 \\
753 \cdot 5\end{array}$ & $\begin{array}{r}8 \cdot 0 \\
327 \cdot 0\end{array}$ & $\begin{array}{r}5 \cdot 7 \\
138 \cdot 0\end{array}$ & $90 \cdot 2$ \\
\hline $\begin{array}{l}\text { (m./mg of protein } \\
\text { (max.) }\end{array}$ & $30 \cdot \theta$ & $4 \cdot 4$ & $325 \cdot 0$ & $400 \cdot 0$ & $285 \cdot 0$ & \\
\hline
\end{tabular}

Results of one of five similar experiments presented in Table 1 indicate that $0.4 \mathrm{M}$ phosphate elutes up to 56 per cent of the 'PN-deaminating' enzyme applied to the column while no 'PHB-deaminating' activity could bo detectod in these fractions. A.t higher phosphate concentrations both enzymatic activities are found in eluates. While up to 90 per cent of initial 'PN-deaminating' activity are recovered in eluates, the recovery of 'PHB. activity' was rather low. Our preliminary observations suggest the phenomenon is causcd by increased lability of thi later enzyme on column chromatography.

Further work on separation and purification of mitochondrial amine oxidases, designated at present by a common term 'monoamine oxidase', as well as investigation of their substrate specificity and effect of inhibitors are in progress and will be published elsewhere in Russian.

\section{Z. GORKIN}

Institute of Biological and Medical Chemistry, Academy of Medical Sciences of the U.S.S.R., Moscow.

1 Zeller, E. A., in The Enzymes, edit. by Sumner, J. B., and Myrbäck, 2, Pt. I, (Academic Press, New York and London, 1051).

${ }^{2}$ Werle, H., and Roewer, F., Biochem. Z., 322, 320 (1952).

${ }^{3}$ Cotzias, G. C., and Greenough, J. J., Nature, 185, 384 (1960).

${ }^{+}$Hardegg, W., and Heilbronn, E., Biochim. Biophys. Acta, 51, 553 (1961). 'Aprison, M. H., Wolf, M. A., Poulos, G. L., and Folkerth, T. L., J. Neurochem., 9, 575 (1962).

'Severina, I. S., and Gorkin, V. Z., Biochimiya (in the press).

${ }^{7}$ Pscheidt, G. R., and Himwich, H. E., Biochem. Pharm., 12, 65 (1963)

${ }^{8}$ Gorkin, V. Z., Kitrossky, N. A., Klyashtorin, L. B., Kommissarova, N. V., Leontyeva, G. A., and Pouchkov, V. A., Biokhimiya (in the press). ${ }^{9}$ Zeller, E. A., Buerki, H. R., and Ishimaru, T., Fed. Proc., 21, 271 (1962).

${ }^{10}$ Schneider, W. C., J. Biol. Chem., 178, 259 (1948).

11 Gorkin, V. Z., and Veryovkina, I. V., Voprosy Med. Khim., 9, 315 (1963)

${ }^{12}$ Gorkin, V. Z., Gridneva, L. I., Romanova, L. A., and Severina, I. S., Biokhimiya, 2\%, 1004 (1962).

${ }^{13}$ Tiselius, A., Hjertén, S., and Levin, ö., Arch. Biochem., 65, 132 (1956).

${ }^{14}$ Roodyn, D. B., Biochem. J., 85, 177 (1962).

${ }^{15}$ Lowry, O. H., Rosenbrough, N. J., Farr, A. L., and Randall, R. J., J. Biol. Chem. 193, 263 (1951)

${ }^{16}$ Brunngraber, E. G., and Aguilar, V., J. Neurochem., 9, 51 (1962).

\section{A Pentose identified in the Carbohydrate Group of Spongin}

Bergmann and Feeney ${ }^{1}$ have isolated a new thymine pentoside from a sponge (Cryptotethia). Isolation and identification of the carbohydrate fragment of this nucleoside have been unsuccessful; but the high dextrorotatory power of this nucleoside suggests that it is a xylofuranoside rather than the as yet unknown thymine nucleoside.

Previously we had examined ${ }^{2}$ the carbohydrate group of a scleroprotein (spongin) and identified the sugar (galactose) by paper chromatography. In the work recorded here we have identified a different sugar (xylose) in the carbohydrate group from Euspongia officinalis.

Euspongia officinalis were cut in very small pieces, mixed with $2 \mathrm{~N}$ hydrochloric acid and shaken in a vacuum several times to remove the calcium carbonate. The material so obtained was washed with distilled water and dried in a vacuum desiccator over phosphorus pentoxide. To $1.5 \mathrm{~g}$ dried sponge were added $150 \mathrm{ml}$. water and this mixture heated for $6 \mathrm{~h}$ at $80^{\circ} \mathrm{C}$ under a reflux condenser on a water-bath, and filtered. The filtrate was concentrated to 1-2 ml. on the water-bath under vacuum (sample I). The same procedure was repeated using hydrolysis with

$\% 1$
Xylose, arabinose,
galactose, mannose
Carbohydrate of spongin
(sample I)
Carbohydrate of spongin
(sample II)
$\% 1$
Xylose
$\% 1$
Arabinose
$\% 1$
Mannose
$\% 1$
Galactose

Fig. 1 